\title{
Low gluten diet in the treatment of adult coeliac disease: effect on jejunal morphology and serum anti-gluten antibodies
}

\author{
A M P MONTGOMERY, A K J GOKA, P J KUMAR, M J G FARThing, \\ AND M L CLARK
}

From the Department of Gastroenterology, St Bartholomew's Hospital, London

SUMmary Treatment of patients with coeliac disease with a low gluten containing diet (LGD) remains controversial. We have studied jejunal morphology and antigluten (AG) antibody titres by ELISA in patients on a LGD of 2.5-5 g/day for three to 14 months (median six months) and compared results with patients on a strict gluten free diet (GFD) for six to 27 months (median 13 months). We found no significant difference in villous height or crypt depth (eight LGD $v 10$ GFD patients) or serum AG-IgA, -IgG, and -IgM titres (13 LGD $v 12$ GFD patients). There was however, a significant increase $(\mathbf{p}<0 \cdot 05)$ in intra-epithelial lymphocytes in those patients on a LGD. We conclude that adult coeliac patients can tolerate a LGD without gross morphological change and without initiating significant AG antibody responses.

After the discovery that gluten is involved in the pathogenesis of coeliac disease, ${ }^{1}$ the medical profession has maintained that a life long strict gluten free diet is mandatory for the health of all patients. ${ }^{23}$ Although there is no doubt that dietary gluten withdrawal results in improvement of clinical symptoms and jejunal morphology, the necessity for total dietary gluten exclusion has been challenged. ${ }^{4}$ Furthermore, despite physicians' recommendations, many patients are unable to maintain a restrictive GFD and continue to ingest small quantities of gluten. ${ }^{56} \mathrm{~A}$ proportion of these patients remain asymptomatic with normal haematological and biochemical parameters. ${ }^{7}$ In view of these findings we believe that a low gluten containing diet (LGD) may be a more realistic treatment for coeliac disease in some patients. This concept, however, remains controversial. ${ }^{\mathrm{k}}$

The aim of the present study was to determine the effects of a LGD on jejunal morphology and serum antibody levels to gluten in a group of coeliac patients we have maintained on a controlled LGD.

Address for correspondence: Dr P J Kumar, Dept of Gastroenterology, St Bartholomew's Hospital, London EC1A 7BE.

Received for publication 1 June 1988.
Methods

PATIENTS

The following patients were included in the study: 13 (seven men) patients (median age, 40 years; range 17-74 years) with untreated coeliac disease, 12 of these patients (seven men) treated with a strict GFD, 13 (six men) coeliac patients ( 25 years; $18-70$ years) on a LGD and 10 (four men) control patients (40 years; $17-74$ years). The control patients consisted of patients with low serum folate concentrations caused by dietary deficiency, or patients with the irritable bowel syndrome with diarrhoea who required gastrointestinal investigation.

Treated coeliac patients had been on a $90-100 \%$ strict GFD for six to 27 months (median 13 months). Each of these patients assessed his or her own diet using a visual analogue scale and underwent formal dietary assessment by a dietician. Patients on a LGD received a list of foods, determined by a dietician, with each item containing $2.5 \mathrm{~g}$ portions of gluten. Low gluten diet patients had consumed $2.5 \mathrm{~g}$ or $5 \mathrm{~g}$ (three patients) of gluten per day for three to 14 months (median six months).

Diagnosis of coeliac disease was based on subtotal villous atrophy at first biopsy and subsequent 
improvement of morphology on a repeat jejunal biopsy after a GFD. All patients had blood tests including a full blood count and serum and red cell folate.

\section{JEJUNAL BIOPSIES}

Jejunal mucosa from duodenojejunal junction was obtained by Crosby capsule. Biopsies suitable for morphometric analysis was obtained from 12 of 13 of the untreated coeliac patients, from 10 of these patients during treatment, from eight patients on the LGD and from eight control patients. The control patients had jejunal biopsies to exclude coeliac disease because of a low red cell folate and gastrointestinal symptoms. In all cases intestinal morphology was found to be normal. Biopsies were fixed in $10 \%$ formal saline and then routinely processed and embedded for paraffin sections.

JEJUNAL MORPHOMETRY

Five micrometre sections of the jejunal biopsies were stained with haematoxylin and eosin. Villous height and crypt depth were measured using an eye piece micrometer. A minimum of 10 well orientated villi and crypts were measured per biopsy specimen. Intra-epithelial lymphocytes per 100 villous enterocytes were recorded, with a minimum of 500 enterocytes counted per patient. " Slides were read blind.

\section{ANTIGLUTEN ANTIBODIES}

Serum antigluten $\operatorname{IgG}, \operatorname{IgM}$, and $\operatorname{Ig} A$ were measured by microplate enzyme linked immunosorbent assay (ELISA). Crude gluten was dissolved in 70:30 solution of methanol: $0 \cdot 1 \mathrm{M}$ Tris buffered saline $\mathrm{pH} 7 \cdot 6$ to a final concentration of $40 \mathrm{mg} / \mathrm{l}$. Fifty microlitres of this solution per well was used to sensitise 96-well polyvinyl plates at $4^{\circ} \mathrm{C}$ overnight. The eighth well of each column was sensitised with $50 \mu$ l of $1 \%$ bovine serum albumin (BSA) as the control well. The plates were washed with PBS containing $0 \cdot 1 \%$ Tween-20 three times and blocked with $1 \%$ BSA during a 60 minute incubation at $37^{\circ} \mathrm{C}$.

Sera were diluted $1: 50$ in $0 \cdot 1 \mathrm{M}$ phosphate buffered saline (PBS) pH 7.6 containing $1 \%$ BSA and serial dilutions made in the plates. Each plate held a serum reference positive for antigluten antibodies. The control well contained the starting dilution of 1:50. After a 60 minute incubation, the plates were washed and $50 \mu \mathrm{l}$ of $1: 1000$ dilution of antihuman $-\operatorname{IgG},-\operatorname{IgA}$, or -IgM-peroxidase conjugate (Sigma, Poole, Dorset) in $1 \%$ BSA was added. Incubation was for 60 minutes followed by a further wash. 3,3,'5,5'tetramethylbenzidine (TMB) was used as peroxidase substrate. ${ }^{11}$ One hundred and fifty microlitres of $0.1 \mathrm{~g} / \mathrm{l}$ solution of TMB in citrate acetate buffer (pH 6) containing $1.3 \mathrm{mmol}_{2} \mathrm{O}_{2}$ was added to each well, the plate incubated at room temperature for 30 minutes and the reaction stopped by the addition of $25 \mu \mathrm{l} 2.35 \mathrm{M}$ sulphuric acid. Optical density (OD) at $405 \mathrm{~nm}$ was read using an ELISA reader (Minireader II, Dynatech, Billinghurst, Sussex). A titre was taken as the reciprocal of the lowest dilution at which the OD reading was $>0 \cdot 05$.

STATISTICAL ANALYSIS

Statistical evaluation of morphometric and ELISA data was carried out by means of a non-paired Wilcoxon's test (non-parametric). Data obtained for patients before and after treatment on a gluten free diet were evaluated using a paired Wilcoxon's test. This study had the approval of the district ethical committee.

\section{Results}

\section{MORPHOMETRY}

There was no difference in villous height or crypt depth between GFD and LGD patients. Villous height was lower $(p<0.01)$ in untreated coeliac patients (median $57 \mu \mathrm{M}$; range 11-207 $\mu \mathrm{M}$ ) compared with LGD patients $(347 ; 171-430)$, GFD patients $(295 ; 231-482)$ and control patients $(422$; $321-487)$. Villous height was higher $(p<0 \cdot 05)$ in control patients compared with GFD patients (Fig. 1). Some patients on a gluten free diet had low villous heights suggesting that they were in fact not adhering to a strict gluten free diet despite stating that they were.

Crypt depth was increased $(\mathrm{p}<0.01)$ in untreated patients $(362 ; 222-482)$ compared with the LGD patients $(146 ; 122-202)$ GFD patients $(163 ; 121-220)$ and the control patients (131; 93-170). Crypt depth was lower $(p<0.05)$ in control patients compared with LGD and GFD patients.

There was an increase $(p<0.05)$ in the IEL count of the LGD patients median $43 / 100$ villous enterocytes; range $22-60)$ compared with GFD $(30 ; 19-51)$ and control patients $(25 ; 18-32)$. The IEL count was higher $(\mathrm{p}<0.01)$ in untreated patients $(67 ; 54-86)$ compared with all other groups (Fig. 2).

ANTIGLUTEN ANTIBODY TITRES

$\mathrm{AG}-\mathrm{Ig} A$ titres in the control group were in the range $0-800$ (median 200). Titres were raised in 11 of the 13 untreated coeliac patients (median titre, 1600; range 200-3200), but decreased after treatment and a strict GFD $(200 ; 0-800 ; p<0 \cdot 01)$. There was no difference in AG-IgA titres between GFD patients, LGD patients (200; 0-3200) and control patients (Fig. 3). One LGD patient had a persistently raised AG-IgA titre (3200), but subsequently admitted to ingesting more than 5 g gluten a day. 


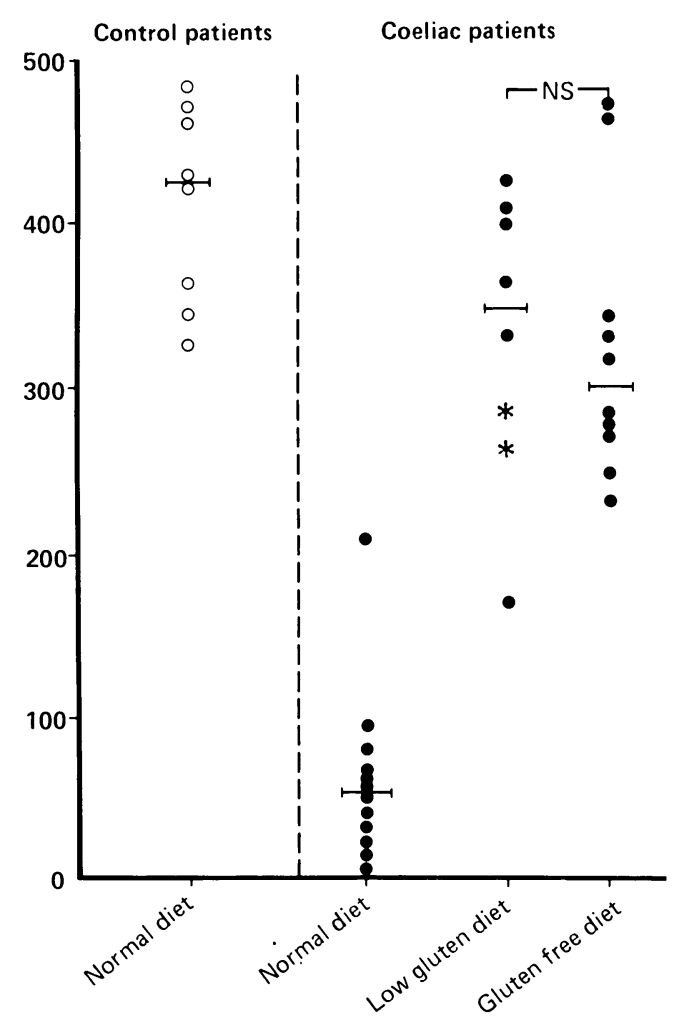

Fig. 1 Villus heights in control patients and patients with coeliac disease according to diet. Horizontal bars represent median values. Stars represent patients on $5 \mathrm{~g}$ of gluten a day.

AG-IgG titres were higher $(p<0 \cdot 05)$ in the coeliac patients compared with the control group. There was, however, no difference in AG-IgG titres between the untreated coeliac patients LGD patients and GFD patients. There was no difference in AGIgM titres between any of the study groups.

B LOOD TESTS

In the coeliac group the serum folate concentrations in the untreated group rose from $1.9 \mu \mathrm{g} / \mathrm{l}$ (range 0.3 to 4.3 ) to $6 \mu \mathrm{g} / \mathrm{l}$ (range 0.6 to $>18$ ) after treatment. In only one patient did the serum folate remain below the normal range after treatment. The red cell folate rose from $134 \mu \mathrm{g} / \mathrm{l}$ (range 69 to 280 ) to $299 \mu \mathrm{g} / \mathrm{l}$ (range 64 to $>640$ ). In four patients the red cell folates remained below the normal range after treatment with a gluten free diet.

In the patients put on a low gluten diet the serum folate fell from $14 \mu \mathrm{g} / \mathrm{l}$ (range $2 \cdot 5$ to $14 \cdot 5$ ) to $6 \cdot 3 \mu \mathrm{g} / \mathrm{l}$ (range 2 to $8 \cdot 4$ ). In only one patient did it remain below normal before and after the low gluten study started suggesting previous ingestion of gluten. The

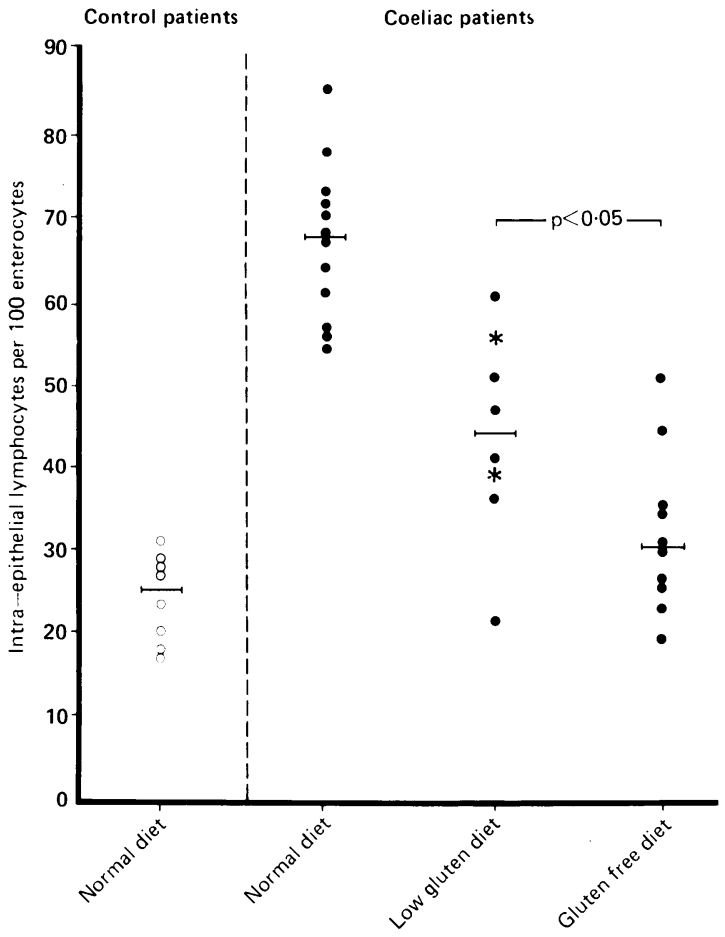

Fig. 2 Intra-epithelial lymphocyte counts in control patients and patients with coeliac patients according to diet.

Horizontal bars represent median values. Stars represent patients on $5 \mathrm{~g}$ of gluten a day.

red cell folates were $303 \mu \mathrm{g} / \mathrm{l}$ (range 122 to 534) before and $262 \mu \mathrm{g} / \mathrm{l}$ (range 173 to 484 ) after the low gluten trial. There were no significant changes in haemoglobin concentration or serum $B_{12}$ concentrations.

\section{Discussion}

Studies of humoral immune responses to gluten and its fractions in coeliac disease are numerous. ${ }^{12-18}$ Raised concentrations of serum antibody to gliadin have been found in $85-100 \%$ of untreated patients, ${ }^{1921}$ and this antibody is predominantly in the $\operatorname{IgA}$ and $\operatorname{IgG}$ classes..$^{212}$ The introduction of a GFD results in a fall of antibody titres, but serum antigliadin-IgG may remain raised for many months. ${ }^{21} 22$ Serum AG-IgA, IgG, and IgM titres shown in this study are in accordance with these observations.

The similarity in AG antibody titres, between LGD and GFD patients suggests that patients can tolerate a regular gluten intake of $2 \cdot 5-5 \mathrm{~g} /$ day without initiating humoral immune responses. Only one LGD patient had a raised AG-IgA titre (3200; Fig. 


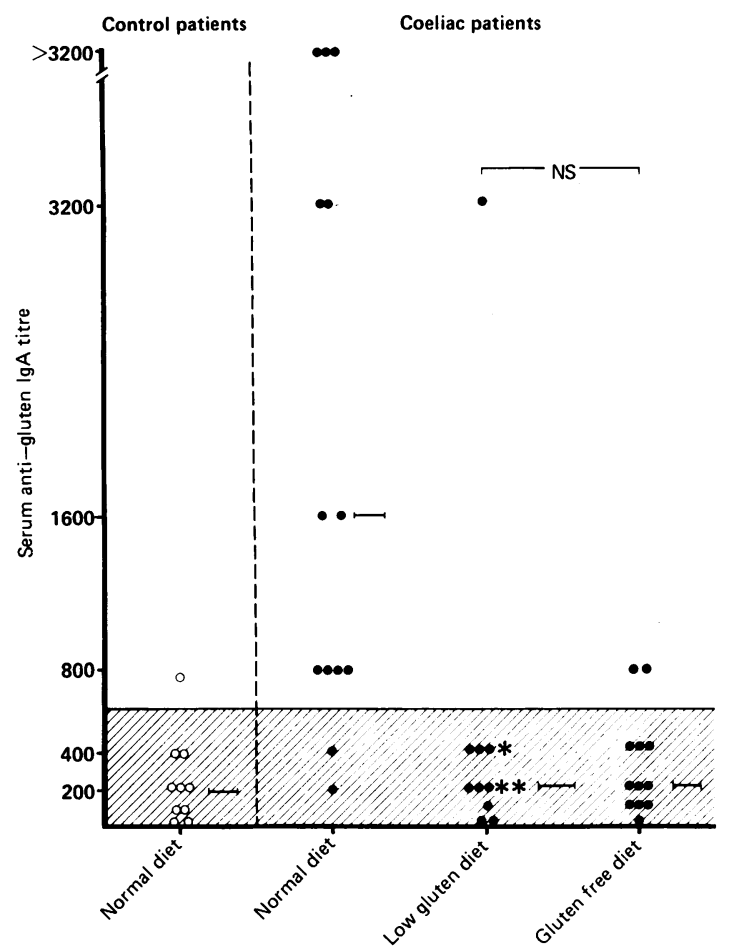

Fig. 3 Antigluten IgA titres in control patients and patients with coeliac disease according to diet. Horizontal bars represent median values. Shaded area represents the normal range for anti-gluten IgA titre (mean control titre $\pm 2 S D$ ). Stars represent patients on $5 \mathrm{~g}$ of gluten a day.

3), and she later admitted to a gluten intake of more than $5 \mathrm{~g}$ /day. Our data further show that a LGD has no significant effect on gross mucosal architecture over the three to 14 month study period. While children and adolescents may take over 12 months to show morphological relapse in response to gluten challenge, ${ }^{23}$ Kumar et $a l^{24}$ have shown that adult patients relapse significantly more quickly after challenge with a minimum of $10 \mathrm{~g}$ gluten/day. Despite a lack of villous atrophy or crypt hyperplasia a small but significant increase in IELs was found in LGD patients. This observation supports previous work, in suggesting that an increase in IELs is a more sensitive indicator of gluten ingestion than partial villous atrophy. ${ }^{525}$

Although there is no doubt that a GFD is beneficial, we believe that the presence or absence of clinical abnormalities is dependent on the amount of gluten ingested, and that small amounts of gluten may be tolerated. McGrae et $\mathrm{al}^{7}$ followed 100 children with coeliac disease who had continued ingesting gluten for over a year after diagnosis. Within this population body weight, serum protein and magnesium were found to be normal and only two of these patients developed symptoms compelling enough to seek medical attention. In a recent study of 85 adult coeliac patients, we found that 27 patients were not maintaining a strict GFD despite the physician's repeated recommendations. These patients were, however, found to be asymptomatic and had normal haematological and biochemical parameters. ${ }^{26} \mathrm{~A}$ parallel can be made with patients with dermatitis herpetiformis where many patients have jejunal mucosal abnormalities of varying severity and have no gastrointestinal symptoms.

In conclusion, we have shown that adult coeliac patients can tolerate a small regular intake of gluten without gross morphological change and without initiating significant $A G$ antibody responses. There was, however, evidence of mild lymphocyte infiltration of the jejunal epithelium in LGD patients, the longterm clinical significance of which is uncertain.

We wish to thank the Joint Research Board of St Bartholomew's Hospital, the NE Thames Regional Health Authority and The Wellcome Trust for financial support of these studies. MJGF is a Wellcome Trust Senior Lecturer.

\section{References}

1 Dicke WK. Coeliakie. Een onderzook naar de nagelige invloed van sommige graansoorten op de ligder aan coeliakie. Utrecht: MD Thesis, 1950.

2 Sheldan W. Prognosis in early adult life of coeliac children treated with a gluten free diet. Br Med J 1969; ii: $401-4$.

3 Young WF, Pringle EM. 110 children with coeliac disease 1950-1969. Arch Dis Child 1971; 46: 421-36.

4 Visakorpi JK, Kuitunen P, Savilahti E. Frequency and nature of relapses in children suffering from the malabsorption syndrome with gluten intolerance. Acta Paediatr Scand 1970; 59: 481-7.

5 Baker PG, Barry RE, Read AE. Detection of continuing gluten ingestion in treated coeliac patients. $\mathrm{Br} \mathrm{Med} \mathrm{J}$ 1975; i: $486-8$.

6 Jackson PT, Glasgow JFT, Thom R. Parents understanding of coeliac disease and diet. Arch Dis Child 1985; 60: 672-4.

7 McCrae, WM, Eastwood MA, Martin MR, Sircus W. Neglected coeliac disease. Lancet 1978; i: 187-90.

$8 \mathrm{McNicholl} \mathrm{B.} \mathrm{Coeliac} \mathrm{disease:} \mathrm{Ecology} \mathrm{life} \mathrm{history} \mathrm{and}$ management. Human Nutr Appl Nutr 1986; 40A: 56-9.

9 Anderson CM, Gracey M, Burke V. Coeliac disease: some still controversial aspects. Arch Dis Child 1972; 47: 292-8.

10 Ferguson A, Murray D. Quantitation of intra-epithelial lymphocytes in human jejunum. Gut 1971; 21: 988-94.

11 Goka AKJ, Farthing MJG. Use of 3,3',5,5'Tetramethylbenzidine in microplate enzyme-linked immunoassay. J Immunoassay 1987; 8: 29-41. 
12 Unsworth DJ, Kieffer M, Holborow EJ, Coombs RRA, Walker-Smith JA. IgA anti-gliadin antibodies in coeliac disease. Clin Exp Immunol 1981; 46: 286-93.

13 Eterman KP, Feltkamp TEW. Antibodies to gluten and reticulin in gastrointestinal disease. Clin Exp Immunol 1978; 31: 92-9.

14 Friis SU, Gudmand-Hoyer E. Screening for coeliac disease in adults by simultaneous determinations of $\operatorname{IgA}$ and IgG gliadin antibodies. Scand J Gastroenterol 1986; 21: $1058-62$.

15 O'Farrelly C, Kelly J, Hekkens W, et al. Gliadin antibody levels: a serological test for coeliac disease. $\mathrm{Br}$ Med J 1983; 286: 2007-10.

16 Juto P, Fredrikzon B, Hernell O. Gliadin-specific serum immunoglobulins $A, E, G$, and $M$ in childhood: Relation to small intestine mucosal morphology. J Pediatr Gastroenterol Nutr 1985; 4: 723-9.

17 Kieffer M, Frazier PJ, Daniels NWR, Coombs RRA. Wheat gliadin fractions and other cereal antigens reactive with antibodies in the sera of coeliac patients. Clin Exp Immunol 1982; 50: 651-60.

18 Ciclitira PJ, Ellis HJ, Richards D, Kemeny DM. Gliadin IgG subclass antibodies in patients with coeliac disease. Int Arch Allergy Appl Immunol 1986; 180: 258-61.

19 Unsworth DJ, Holborow EJ, Kumar PJ, Ellis A, McConnell RB. Gliadin antibody levels in screening tests for coeliac disease. Br Med J 1984; 288: 69-70.
20 Volta U, Lenzi M, Lazzari R, et al. Antibodies to gliadin detected by immunofluorescence and a micro-ELISA method: markers of active childhood and adult coeliac disease. Gut 1985; 26: 667-71.

21 Scott H, Ek J, Brandtzaeg P. Changes of serum antibody activities to various dietary antigens related to gluten withdrawal or challenge in children with coeliac disease. Int Arch Allergy Appl Immunol 1985; 76: 138-44.

22 Savilahti E, Perkkio M, Kalimo K, Viander M, Vainio E, Reunala T. IgA antigliadin antibodies: A marker of mucosal damage in childhood coeliac disease. Lancet 1983 ; i: $320-2$.

23 Hamilton JR, McNeill LK. Childhood coeliac disease: Response of treated patients to a small uniform daily dose of wheat gluten. J Pediatr 1972; 81: 885-93.

24 Kumar PJ, O’Donoghue DP, Stenson K, Dawson AM. Reintroduction of gluten in adults and children with treated coeliac disease. Gut 1979; 20: 743-9.

25 Leigh RJ, Marsh MN, Crowe P, Kelly C, Garner V, Gordon D. Studies of intestinal lymphoid tissue. Dosedependent gluten induced lymphoid infiltration of coeliac jejunal epithelium. Scand J Gastroenterol 1985; 20: 715-9.

26 Kumar PJ, Harris G, Colyer J, Clark ML, Dawson AM. Is a gluten free diet necessary for the treatment of coeliac disease. [Abstract]. Gastroenterology 1985; 88: 1459. 